\title{
DEVELOPMENT OF Chrysomya albiceps WIEDEMANN, 1819 (DIPTERA: CALLIPHORIDAE) AND Musca domestica LINNAEUS, 1758 (DIPTERA: MUSCIDAE) REARED TOGETHER IN PIG TISSUES.
}

\author{
Cíntia de Campos Chaves, Manuela Campos Ferreira and Júlio Mendes
}

\begin{abstract}
Chysomya albiceps and Musca domestica are important for forensic entomology, and human and animal health. This study analyzed the effects of the coexistence of $C$. albiceps and $M$. domestica reared in four different assays in two pig tissues, brain and intestine: assay 1, interaction between the larvae of the same age; assay 2, interaction between larvae of C. albiceps 24 hours older than larvae of $M$. domestica; assay 3, interaction between larvae of $M$. domestica 24 hours older than the larvae of C. albiceps; assay 4, larvae of both species were reared together in flasks with a small supply of food. Weight of larvae, growth time and imago emergence frequency were studied. C. albiceps responded better than $M$. domestica under most conditions tested. Larvae of $C$. albiceps responded better in mixed cultures (together with $M$. domestica) than in pure cultures (larvae of the same species). In contrast, $M$. domestica responded better when reared in pure cultures. Both species presented shorter growth times when their larvae were reared in intestine tissue with larvae 24 hours younger than the larvae of the concurrent species, compared to their respective growth times in pure cultures. The results confirmed that trophic interactions are relevant to the successful colonization of carrion by $C$. albiceps. Coexistence of the two species may result in changes in values of their biological components. The results also help to shed light on the biology of the two species in carrion.
\end{abstract}

KEY WORDS: Chrysomya albiceps; Musca domestica; pig tissues; competition; medical forensic entomology.

\section{INTRODUCTION}

Carrion is routinely colonized by insects which belong to various ecological categories. The coexistence of different species in this substrate is common, leading to trophic interactions during decomposition. Interactions such as competition and predation may affect the growth and the richness of the breeding fauna in this temporary habitat (Hanski, 1987a). Studies focusing on competition and predation improve the understanding of the consequences of these interactions in the life cycles of insects and contribute to explain, at least partly, why some flies are absent, scarce or dominant in these ephemeral resources.

\footnotetext{
Departamento de Parasitologia, ICBIM, Universidade Federal de Uberlândia, Uberlândia, MG, Brazil.
}

Corresponding author. Júlio Mendes, Instituto de Ciências Biomédicas, Setor de Parasitologia, Av. Amazonas, s/nº, Universidade Federal de Uberlândia, Caixa Postal 593, CEP 38405-302, Uberlândia, MG, Brazil. E-mail: jmendes@ufu.br 
The media, in which the flies breed, such as carrion, can be crucial for their survival. Some species can change their physiology in attempts to offset environmental stress. Growth time, survival rate, weight and size may be influenced by several factors including food shortages, competition and predation (Hanski, 1987a; Aguiar-Coelho \& Milward-de-Azevedo, 1998; Faria et al., 2001). As a result, some individuals may die while the survivors may experience changes in some of their biological components such as: growth time, weight and size. These changes can influence the degree of fly success and may affect the dynamics of their populations in an environment (Hanski, 1987b). In turn, survivors with altered biological components could be used as biomarkers in applied biology. Insight concerning these issues in carrion could increase the accuracy of inferences from parameters used in some areas of applied biology, including medical forensic entomology.

Blowflies, Chrysomya spp. (Diptera: Calliphoridae) were introduced into the American Continent over the past three decades. The larvae belonging to the species introduced into the New World are saprophagic (Guimarâes \& Papavero, 1999). Chrysomya albiceps Wiedemann 1819 is an agent of secondary myiasis and can transmit pathogens to humans and other animals (Zumpt, 1965; Greenberg, 1971; Guimarães \& Papavero, 1999). This has been the dominant species breeding in pig carrion in several countries of the New World (Souza \& Linhares, 1997; Centeno et al., 2002; Montoyag et al., 2009; Faria et al., 2013). Studies have shown that $C$. albiceps has a remarkable ability to survive and to compete with other fly species; larvae of second and third instars of this species are facultative predators or cannibals (Aguiar-Rabbit \& Milward-de-Azevedo 1998; Faria et al., 2004). Studies have demonstrated that various blowflies, including $C$. albiceps, breed in most carcass tissue (Kaneshrajah \& Turner 2004; Clark et al., 2006, Beuter \& Mendes, 2013), justifying their great capacity for exploiting carrion.

Musca domestica L 1758 (Diptera: Muscidae) is a cosmopolitan species highly adapted to anthropic environments. This species visits and breeds in garbage dumps, feces and other organic debris (Ferrar, 1987; Byrd \& Castner 2009). The house fly has been found carrying several pathogens such as viruses, bacteria, protozoa cysts, and helminth eggs. As adult flies normally visit unprotected human food, this species is considered an important vector of several pathogens that cause diseases to humans such as cholera, dysentery, gastroenteritis and typhoid fever (Greenberg, 1971; Graczyk et al., 2001). The house fly is commonly found visiting carrion but until recently, it was not normal to see this fly breeding in medium sized animal carcasses (Smith 1986; Byrd \& Castner, 2009; Barreto et al., 2002; Arnaldos et al., 2005; Vasconcelos \& Araujo, 2012; Tabor et al., 2005; Salazar, 2006; Vitta et al., 2007; Faria et al., 2018). Nevertheless, the increase in studies in medical forensic entomology in many parts of the world, including Brazil, has produced numerous reports of this species breeding in these carcasses (Carvalho et al., 2004; Chen et al., 
2010; Grisales et al., 2010; Vasconcelos \& Araujo, 2012; Faria et al., 2013) and in human corpses (Chandna, 2012). It has been assumed that house fly growth in carcasses occurs when excrement and/or intestinal contents are left exposed (Smith, 1986). However, laboratory studies have shown that this species is capable of breeding in various pig tissues, such as flesh, brain and intestinal tissues (Costa \& Mendes, 2014).

As mentioned, C. albiceps and $M$. domestica show great disparities in their breeding performances in medium-sized carcasses. These disparities are partly explained by differences in their individual capacity to explore these resources (Beuter \& Mendes, 2013; Costa \& Mendes, 2014). Trophic interactions are other factors that could influence their respective performances. In this study, C. albiceps and M. domestica were reared together in pig tissues in the laboratory. Assays were conducted to analyze the effects of the association between their immatures under four different conditions and two different pig tissues, intestine and brain. Weight of larvae, time to complete their growth and imago emergence frequencies were studied.

\section{MATERIAL AND METHODS}

Maintenance of $\mathrm{C}$. albiceps and $\mathrm{M}$. domestica in the laboratory

The study was conducted in the Laboratory of Entomology (LE) of the Department of Parasitology, Institute of Biomedical Sciences (ICBIM) at the Federal University of Uberlândia, in Uberlândia, State of Minas Gerais, Brazil. C. albiceps and M. domestica were collected in open air environments using baited traps with rodent carcasses, pig intestine and flesh (Ferreira, 1978). In the laboratory, adults were transferred to entomological cages. The larvae were transferred, with their respective bait, into flasks maintained at room temperature until the emergence of imagoes, which were also transferred to entomological cages (Beuter \& Mendes, 2013). Flies were identified using an identification key (Carvalho \& Mello-Patiu, 2008). Feeding and breeding substrates used to maintain the colonies included ground pork and ground beef for $C$. albiceps and a 1:1 mixture of ground beef and macerated chicken feed for $M$. domestica. A sugar solution was offered ad libitum to flies in bottles containing gauze partially immersed in the solution. The above-mentioned substrates were used to obtain eggs to perform the assays.

Eggs obtained from females of the respective species were transferred to Petri dishes containing filter paper and cotton soaked in distilled water. Subsequently, the dishes were placed in a climatic chamber (Nova Tecnica Inc) at $25 \pm 0.5^{\circ} \mathrm{C}$ until the larvae hatched. Up to two hours after hatching, neolarvae of the two species were reared together (mixed cultures) and separately 
(pure cultures) in pig intestine and brain tissues, in four different assays for interaction between the two species. The intestine tissue was provided with residues of its contents. The substrates/tissues had been previously maintained at $25 \pm 2^{\circ} \mathrm{C}$ for $24 \mathrm{~h}$ before being used as food supply for the larvae.

\section{Interaction Assays}

Three of the four assays consisted of six flasks with replicates containing $120 \mathrm{~g}$ of food and mixed cultures with 50 larvae of each species and four additional flasks with pure cultures of the two species: two containing 100 larvae of $C$. albiceps each, and two containing 100 larvae of $M$. domestica each. The fourth assay was performed using a smaller amount of food for the same number of larvae used in each flask of the preceding assays. The assay with larvae of $M$. domestica older than larvae of $C$. albiceps was performed using only the intestine substrate.

The larvae of the two species were reared in the four following conditions: assay 1, interaction between the larvae of the two species of the same age: neo-larvae of $C$. albiceps and $M$. domestica were reared together supplied with $120 \mathrm{~g}$ of food. Assay 2, interaction between larvae of C. albiceps $24 \mathrm{~h}$ older than larvae of $M$. domestica: initially, 50 neo-larvae of $C$. albiceps were transferred to flasks supplied with food substrate, then $24 \mathrm{~h}$ later, 50 neo-larvae of $M$. domestica were also added to the flasks and the larvae of different ages were reared together. Assay 3, interaction between larvae of $M$. domestica $24 \mathrm{~h}$ older than larvae of $C$. albiceps; i.e., the reverse assay 2: larvae of $M$. domestica, $24 \mathrm{~h}$ older than larvae of $C$. albiceps were reared together. Assay 4, larvae of $C$. albiceps and $M$. domestica were reared in flasks with a small amount of food. Fifty neo-larvae of each species were reared together in four replicate flasks, each supplied with $70 \mathrm{~g}$ of feed substrate. Two additional flasks, each containing little food and 100 larvae of the same species were reared under the conditions described above.

All flasks were kept in a climatic chamber at $25 \pm 0.5{ }^{\circ} \mathrm{C}$ and $60 \%$ $\pm 10 \%$ relative humidity for a $12 \mathrm{~h}$ photoperiod. Larval development was monitored daily. When the larvae left the substrate to pupate, five of each species from each replicate flask were weighed using an analytical balance and subsequently returned to the original flasks. Approximately 30 larvae from experimental flasks and 12 larvae from control groups (pure culture) were weighed in each assay. Particularly for $M$. domestica, because of the extensive mortality of larvae in flasks containing mixed cultures, the number of weighed larvae from those flasks varied from 12 to 30 . 


\section{Statistical analysis}

Larvae weights and imago emergences of $C$. albiceps and $M$. domestica in all assays, from each food and from mixed and pure cultures (control groups) were compared. Next, results obtained from the mixed cultures were compared with those of the same species obtained in pure cultures in each assay. The imago emergence frequencies for each species were compared in each assay in two situations: comparisons among frequencies of the same species obtained in the mixed cultures versus those obtained in pure cultures, and comparisons between imago emergence frequencies of different species reared in the mixed cultures. Preliminarily, the data were transformed to log $\mathrm{n}+1$, and then compared using ANOVA. Multiple comparisons that resulted in significant results were subjected to the Tukey test. Statistical analyses were performed using the significance level of $5 \%$.

\section{RESULTS}

The general imago emergence frequencies for the two species obtained in the four assays presented significant differences $(\mathrm{F}=6.184, \mathrm{p}=0.020)$. Larvae weights and imago frequencies for $C$. albiceps obtained in the two food supplies did not differ significantly. In contrast, $M$. domestica presented higher imago emergence frequencies in intestine than in brain tissue $(\mathrm{F}=9.419$; $\mathrm{p}=0.018$ ). Relative imago emergence frequencies for each species obtained in the assays with sufficient food did not differ significantly from their respective frequencies obtained in the assay with little food ( $\mathrm{F}=2.207, \mathrm{P}=0.168 ; \mathrm{F}=1.864$, $\mathrm{p}=0.202$ ). The food reduction was not sufficient to interfere in the imago frequencies for $M$. domestica emerged in the pure cultures and of $C$. albiceps emerged in the mixed cultures (Table).

When the two species were compared in each assay, C. albiceps demonstrated better performance than $M$. domestica in most of the tested conditions in mixed cultures. Larvae of $C$. albiceps reared with younger larvae of $M$. domestica in mixed cultures presented greater weights than those reared in pure cultures (Table). The frequencies of C. albiceps were higher in mixed culture, when reared with $M$. domestica, than when reared in pure cultures in most of the assays. The only exception was observed in the assay where larvae of $C$. albiceps were reared in intestine tissue with older larvae of $M$. domestica. Comparisons between imago emergence frequencies for $M$. domestica and C. albiceps obtained in mixed cultures also showed significant differences between the two species $(\mathrm{F}=10.92, \mathrm{p}=0.01)$. Although weight comparisons of larvae of $M$. domestica reared in pure and mixed cultures did not present significant differences, the emerging imagoes of this species were fewer in numbers in the mixed cultures (Table). 


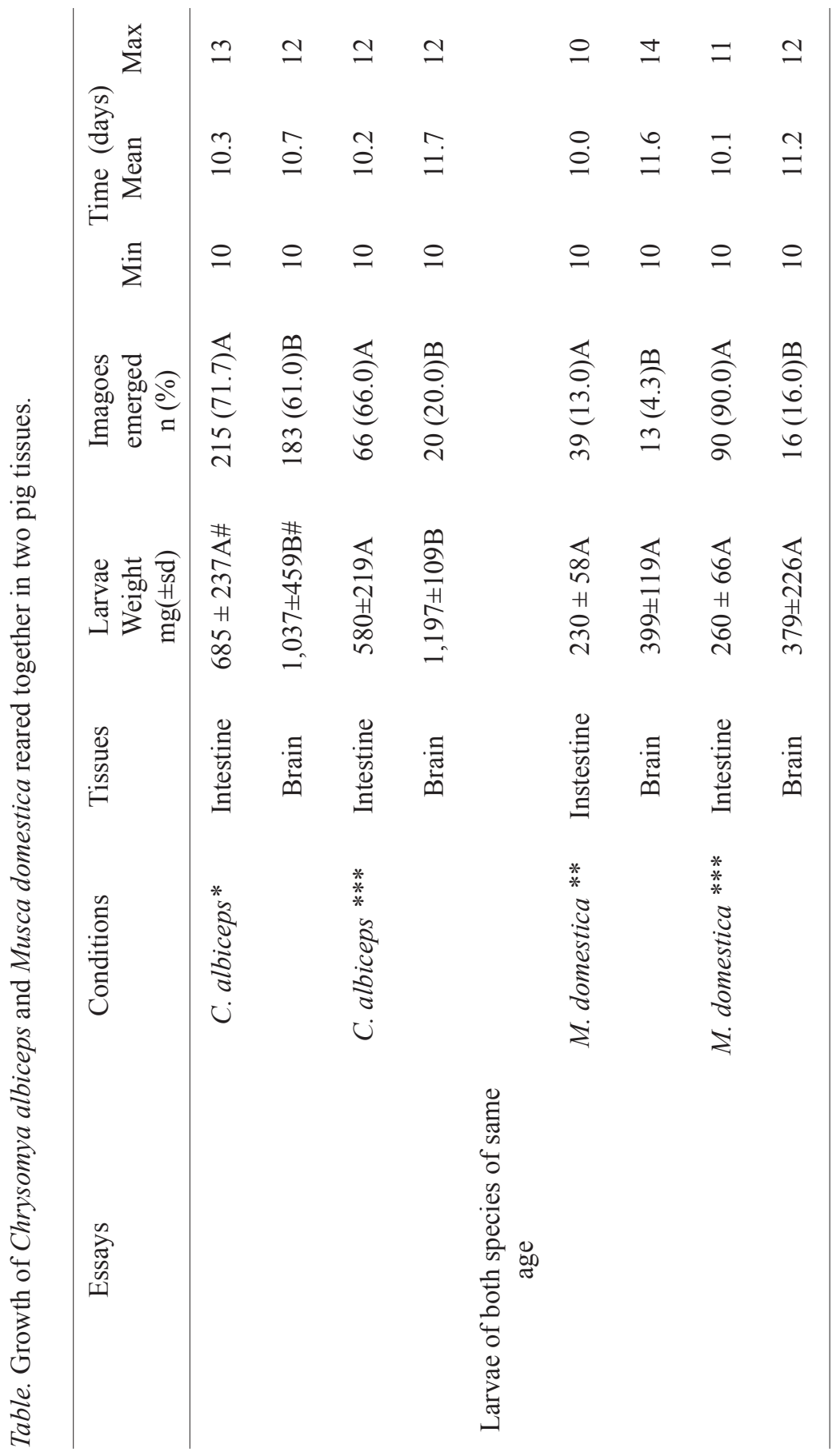




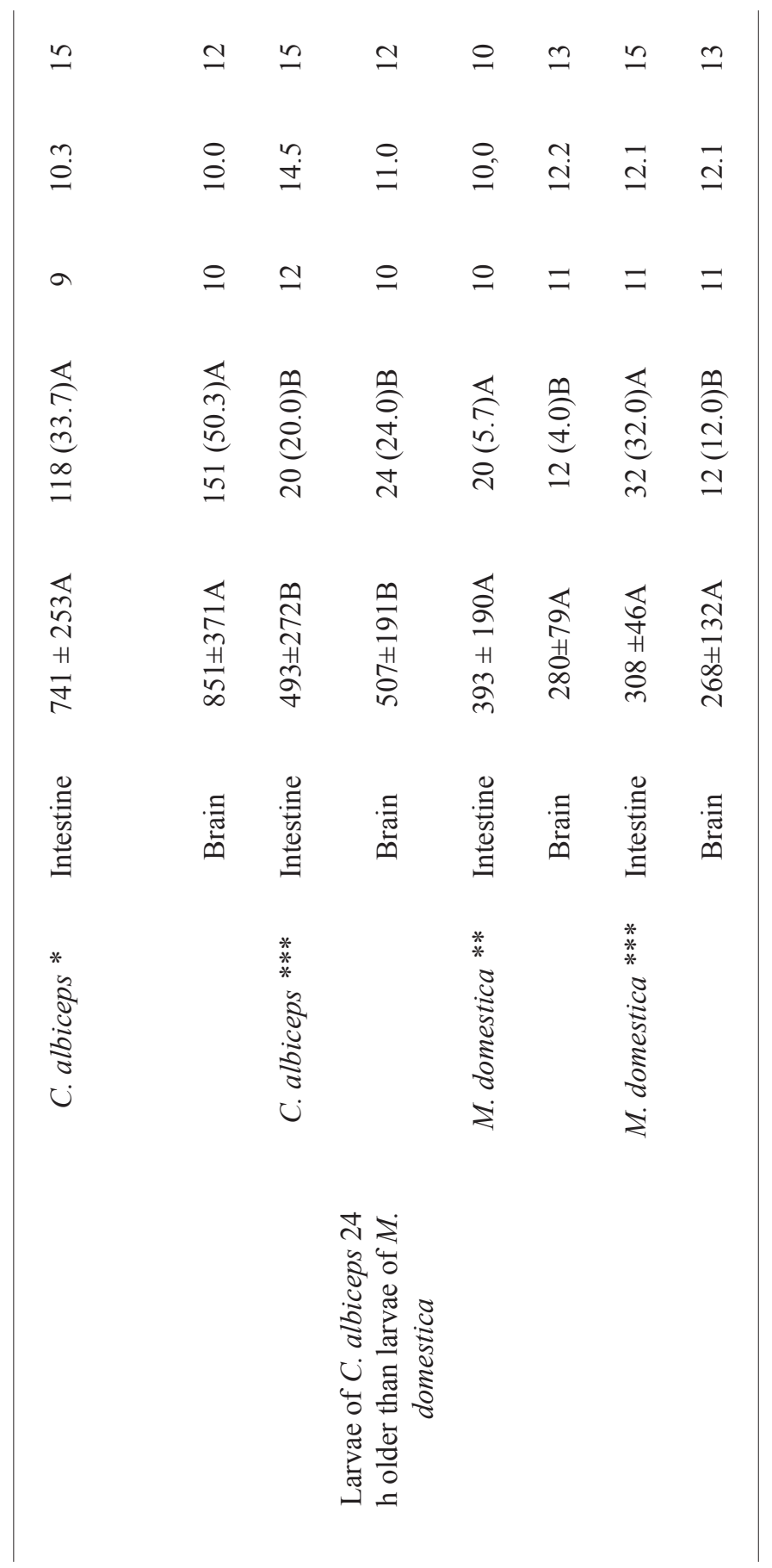




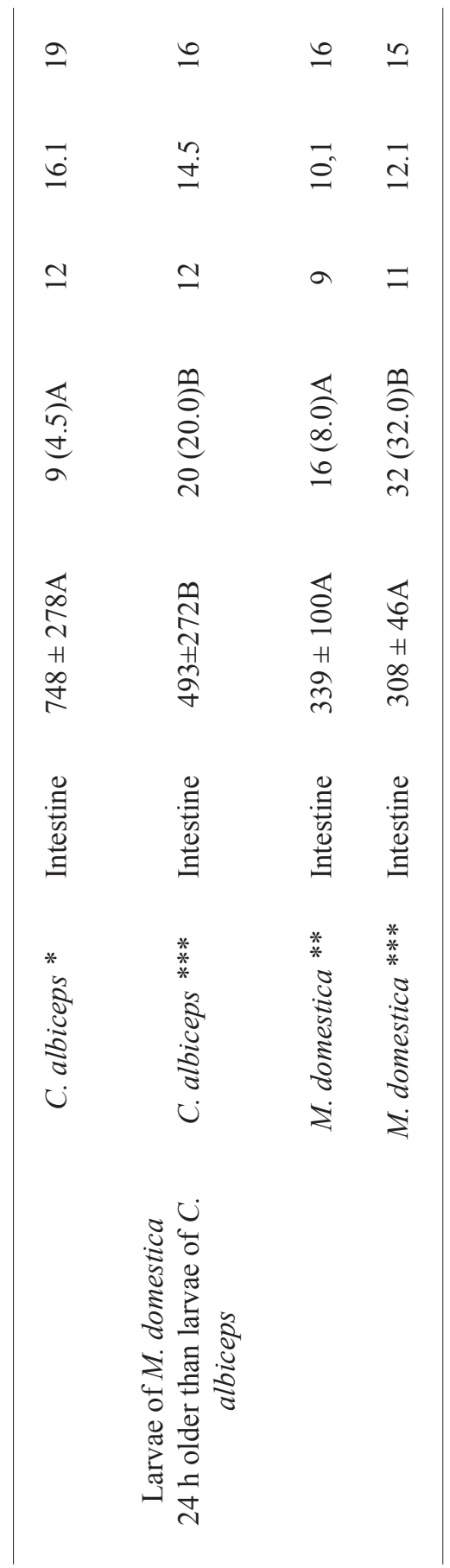




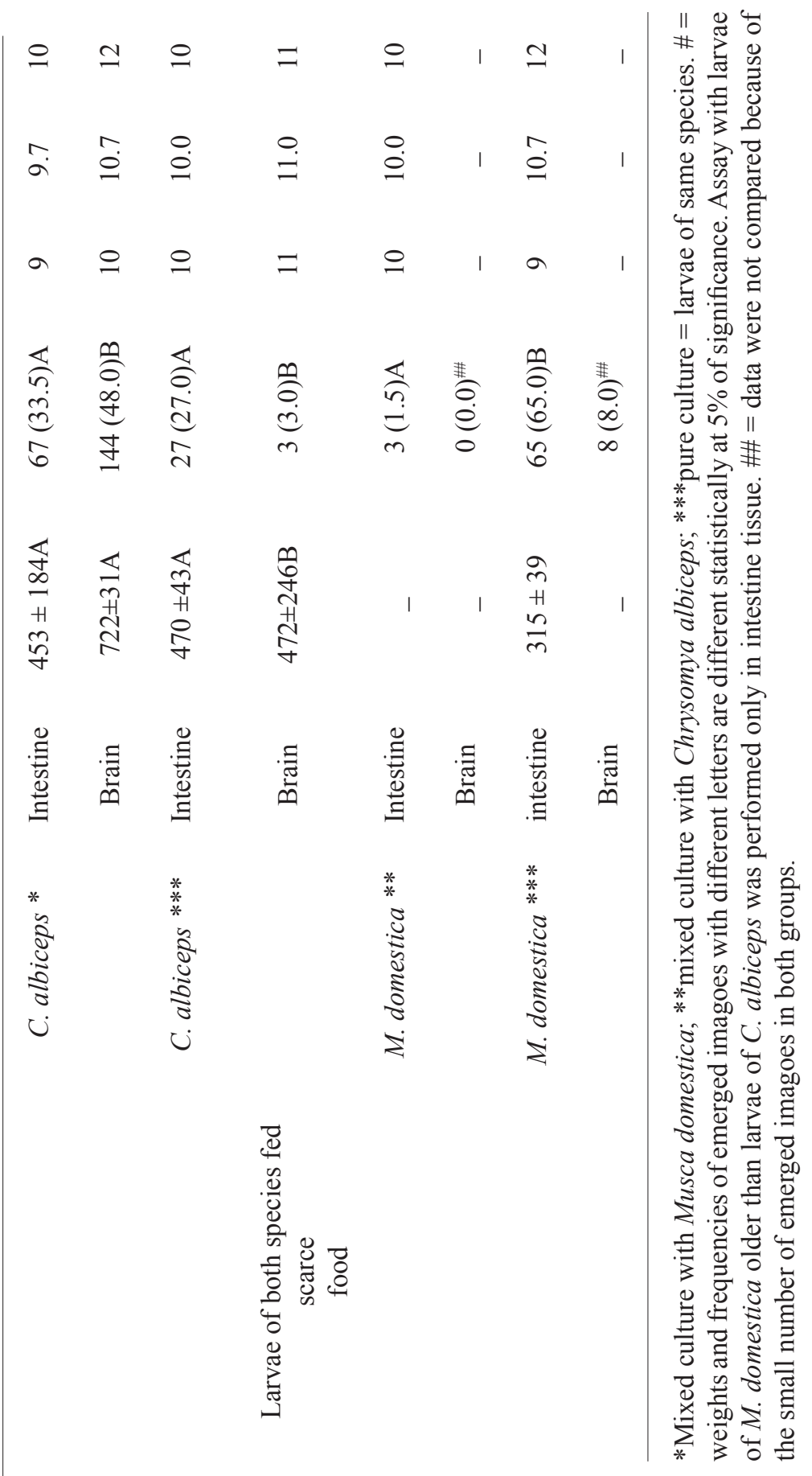


M. domestica presented a delay in the imago emergence peaks when its larvae were reared with C. albiceps in most of the assays (Figures 1 and 2). As a result, the mean time for emergence of $M$. domestica imagoes was longer under this condition, compared with the mean time for imago emergence in pure cultures (Table). C. albiceps presented earlier imago emergence peaks in mixed cultures (Figures 1 and 2) consequently, the mean time for imago emergences was shorter in this condition. Once again, an exception was observed when $C$. albiceps larvae were reared in intestine tissue along with older larvae of $M$. domestica (Table).

Results regarding the minimum growth time obtained from both species varied considerably. The two species presented variations in this parameter mainly when reared in mixed cultures with larvae of the concurrent species of different ages and in scarce breeding media. Both species presented different growth times compared to the respective control groups when their respective larvae were reared in intestine tissue with younger larvae of the other species. C. albiceps presented a shorter growth time in the mixed culture reared in little intestine tissue, whereas $M$. domestica presented a shorter growth time in the pure culture in this assay (Table).
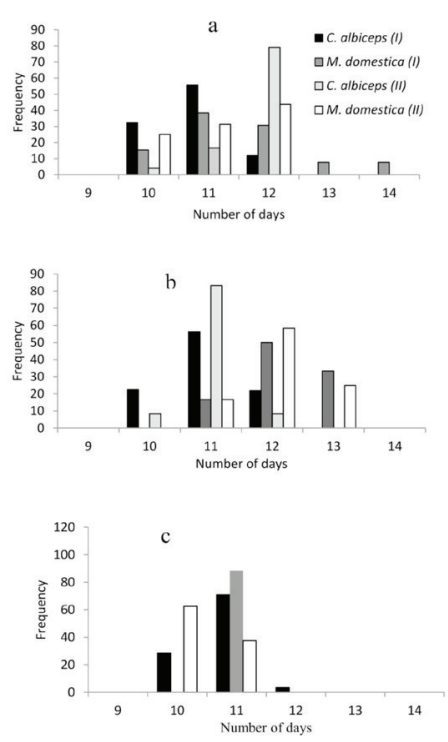

Figure 1. Time distribution of imago emergence frequencies for Chrysomya albiceps and Musca domestica reared in mixed and pure cultures in pig brain tissue under four different conditions: $a=$ larvae of the same age; $b=C$. albiceps older than $M$. domestica; $\mathrm{c}=M$. domestica older than C. albiceps; (I) $=$ mixed cultures. (II) $=$ pure cultures. 

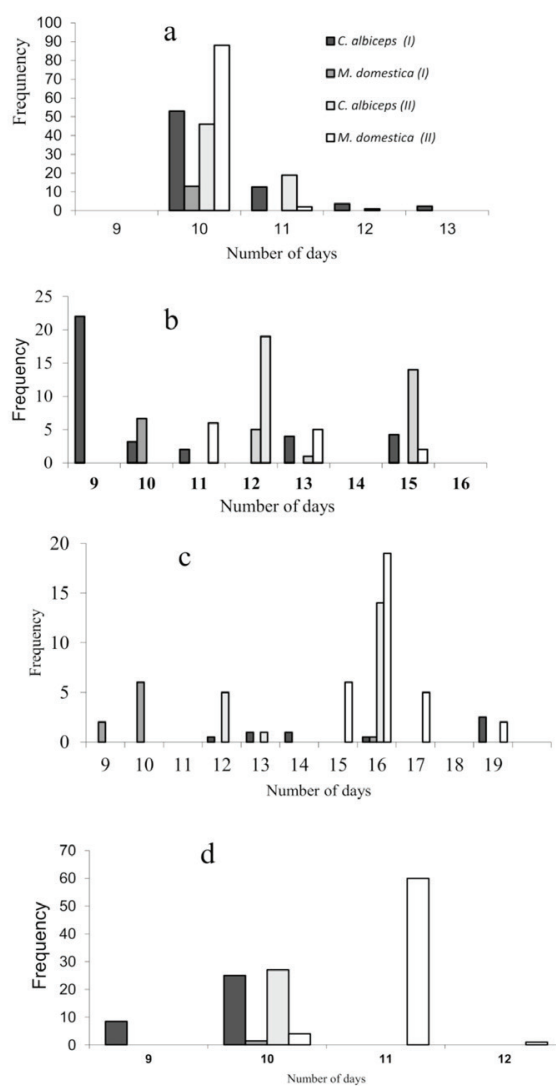

Figure 2. Time distribution of imago emergence frequencies for Chrysomya albiceps and Musca domestica reared in mixed and pure cultures in pig instestine tissue under three different conditions: $a=$ larvae of the same age; $b=$ C. albiceps older than $M$. domestica; $\mathrm{c}=$ larvae bred on little food; $\mathrm{d}=$ larvae bred on little food. (I) = mixed cultures; (II) = pure cultures.

\section{DISCUSSION}

C. albiceps is capable of exploring various resources in carrion (Carvalho et al., 2007; Beuter \& Mendes, 2013). Moreover, this species is among the first to colonize this substrate and may act as a facultative predator/ cannibal (Faria et al., 1999; Faria \& Godoy, 2001; Centeno et al., 2002; Faria et al., 2013). Better breeding performance of C. albiceps than $M$. domestica in carrion tissues was expected, especially in cultures in which its larvae were older than those of $M$. domestica. The fact that $C$. albiceps was also favored 
when coexisting with $M$. domestica larvae of the same age, indicates that it has a comparative advantage over such species when breeding in carrion. Studies have also observed a better breeding performance of $C$. albiceps in mixed cultures in comparison to other species of blowflies (Aguiar-Coelho \& Milward-de-Azevedo, 1998; Faria \& Godoy, 2001). These results strengthen the perception that $C$. albiceps also has a comparative advantage over other fly species found in carrion.

The numerous variations in the imago emergence frequencies which occurred in each assay were also noteworthy. These variations were probably influenced by the interaction between the two species, their respective capacity for exploring the food and by the food availability for each of them. C. albiceps presented a reasonable performance of imago emergence in both types of food, mainly when reared with $M$. domestica. In contrast, $M$. domestica presented a greater proportions of imago emergences in intestine tissue and in pure cultures. Post-feeding larvae of $M$. domestica are smaller and lighter than those of C. albiceps (Beuter \& Mendes, 2013, Costa \& Mendes, 2014). The need for a smaller quantity of food for larvae of $M$. domestica to achieve their growth and the absence of negative interactions with the concurrent species would explain its good performance in pure cultures in the assay containing little food. However, the good performance of $C$. albiceps in the mixed culture in this same assay would be influenced by its interaction with the larvae of $M$. domestica.

Intestine tissue is recognized as an effective carrion source for rearing house fly larvae (Costa \& Mendes, 2014). The good performance of $M$. domestica in this substrate was expected. In this research, intestine tissue was offered with residues of its contents, a substrate considered efficient for the growth of its larvae (Smith, 1986; Larrain \& Salas, 2008; Faria et al., 2013). The results from pure cultures in brain tissue also proved the worthiness of this tissue as a food supply for its larvae (Costa et al., 2014). Nevertheless, breeding with younger larvae of $C$. albiceps was the only condition in which $M$. domestica larvae presented a better performance than this species in mixed cultures. Since $C$. albiceps is among the first species to colonize carrion (Centeno et al., 2002; Faria et al., 2013), the coexistence of larvae of $M$. domestica and C. albiceps of the same age or older may be more common than the reverse. Although the house fly has been observed as an early visitor (Chin et al., 2008), the colonization and coexistence of the two species may be more common when the abdominal area of the corpse suffers disruption of the intestines and the contents are exposed. Under natural conditions, this event occurs in the second stage of decomposition (Bornemissza, 1957, Smith, 1986) coinciding with the time when M. domestica has been seen visiting and breeding in the carrion (Carvalho et al., 2004; Voss et al., 2008; Rosa et al., 2009; Chandna, 2012). 
The results attest that trophic interactions are an important restrictive factor influencing the survival of immatures of $M$. domestica in carrion. Competition and predation interaction explain, at least partly, why its immature forms commonly do not complete their growth in this substrate (Chin et al., 2008).

The coexistence of $C$. albiceps and $M$. domestica influenced their respective biological components including: respective weights, growth times and imago emergence frequencies with both species presenting opposite results under most test conditions.

Weight of larvae and minimum growth time are parameters commonly used to calculate the postmortem interval (PMI) in medical forensic entomology (MFE). If, in applied studies of MFE, C. albiceps and M. domestica are found breeding together, the influence of their coexistence on the respective biological components should be considered in estimates such as PMI. The results presented here also help to shed light on the biology of these two flies of medical and veterinary interest, when bred in ephemeral resources such as carrion.

\section{REFERENCES}

1. Aguiar-Coelho VM, Milward-de-Azevedo EMV. Combined rearing of Cochliomyia macellaria (Fabr.), Chrysomya megacephala (Fabr.) and Chrysomya albiceps (Wied.) (Dipt., Calliphoridae) under laboratory conditions. J Appl Entomol 122: 551-554, 1998.

2. Arnaldos MI, García MD, Romera E, Presa JJ, Luna A. Estimation of post-mortem interval in real cases based on experimentally obtained entomological evidence. Forensic Sci Int 149: 57-65, 2005.

3. Barreto M, Burbano ME, Barreto P. Flies (Calliphoridae, Muscidae) and Beetles (Silphidae) from Human Cadavers in Cali, Colombia. Mem Inst Oswaldo Cruz 97: 137-138, 2002.

4. Beuter L, Mendes J. Development of Chrysomya albiceps (Wiedemann) (Diptera: Calliphoridae) in Different Pig Tissues. Neotrop Entomol 42: 26-430, 2013.

5. Bornemissza GF. An Analysis of arthropod succession in carrion and the effect of its decomposition on the soil fauna. Aust J Zool 5: 1-12, 1957.

6. Byrd JH, Castner JL. Forensic Entomology: The Utility of Arthropods in Legal Investigations. 2nd Ed CRC Press: Kansas, 2009. 705p.

7. Carvalho CJB, Mello-Patiu CA. Key to the adults of the most common forensic species of Diptera in South America. Rev Bras Entomol 52: 390-406, 2008.

8. Carvalho LML, Thyssen PJ, Goff ML, Linhares AX. Observations on the Succession Patterns of Necrophagous Insects on a Pig Carcass in a Urban Area of Southeastern Brazil. Aggrawal's Int J Forensic Med Tox 5: 33-39, 2004.

9. Carvalho ML, Palhares FAB, Linhares AX. Malignant Tumor Affects the Developmental Pattern of Feeding Larvae of Chrysomya albiceps (Wiedemann) and Chrysomya putoria (Wiedemann) ( Diptera: Calliphoridae). Neotrop Entomol 36: 478-481, 2007.

10. Centeno N, Maldonado M, Oliva A. Seasonal patterns of arthropods occurring on sheltered and unsheltered pig carcasses in Buenos Aires Province (Argentina). Forensic Sci Int 126: 63-70, 2002 . 
11. Chen CD, Lee HL, Nazni WA, Ramli R, Jeffery J, Sofian-Azirun M. First report of the house fly larvae, Musca domestica ( Linnaeus) (Diptera: Muscidae) associated with the monkey carcass in Malaysia. Trop Med 27: 355-359, 2010.

12. Chandna SS. Insects in Forensic Science for Detection for Crime. New York Sci J 5: 27-31, 2012.

13. Chin HC, Marwi MA, Jeffery J, Kurahashi H, Omar B. On the occurrence of Musca domestica L oviposition activity on pig carcass in peninsular Malaysia. Trop Biomed 25: 252-253, 2008.

14. Clark K, Evans L, Wall R. Growth rates of the blowfly, Lucilia sericata, on different body tissues. Forensic Sci Int 156: 145-149, 2006.

15. Costa LV, Mendes J. Musca domestica (Diptera: Muscidae) breeding in various pig tissues. Rev Patol Trop 43: 360-368, 2014.

16. Faria LDB, Trinca LA, Godoy WAC. Larval predation by Chrysomya albiceps on Cochliomyia macellaria, Chrysomya megacephala and Chrysomya putoria. Entomol Exp Appl 90: 149-155, 1999.

17. Faria LDB, Godoy WAC. Prey choice by facultative predator larvae of Chrysomya albiceps (Diptera: Calliphoridae). Mem Inst Oswaldo Cruz 96: 875-878, 2001.

18. Faria LS, Paseto ML, Franco ML, Perdigão VC, Capel G, Mendes J. Insects Breeding in Pig Carrion in Two Environments of a Rural Area of the State of Minas Gerais, Brazil. Neotrop Entomol 42: 216-222, 2013.

19. Faria LS, Paseto ML, Couri MS, Mello-Patiu CA, Mendes J. Insects Associated with Pig Carrion in Two Environments of Brazilian Savanna. Neotrop Entomol 47: 181-198, 2018.

20. Faria LDB, Trinca LA, Godoy WAC. Cannibalistic behavior and functional response in Chrysomya albiceps (Diptera: Calliphoridae). J Insect Behav 17: 251-259, 2004.

21. Ferrar P. A guide to the breeding habits and immature stages of Diptera Cyclorrhapha. E.J. Brill/Scandinabian Science Press, Leiden, Copenhagen, Enomonograph 8: 1-8, 1987.

22. Ferreira MJM. Sinantropia de dípteros muscóides de Curitiba, Paraná, I. Calliphoridae. Rev Bras Biol 58: 445-454, 1978.

23. Greenberg B. Flies and disease, vol. 1. Ecology classification and biotic associations. Princeton University Press: Princeton, 1971. 856p.

24. Grisales D, Ruiz M, Villegas S. Insects associated with exposed decomposing bodies in the Colombian Andean Coffee Region. Rev Bras Entomol 54: 637-644, 2010.

25. Graczyk T, Knight R, Gilman R, Cranfield $H$. The role of non-biting flies in the epidemiology of human infectious diseases. Microbes Infect 3: 231-235, 2001.

26. Guimarães JH, Papavero N. Myiasis in man and animals in the Neotropical region. EP Editora Plêiade: São Paulo, 1999. 308p.

27. Hanski I. Nutritional ecology of dung-and carrion-feeding insects. In: Slaniki F J R, Rodrigues JG (eds) Nutricional ecology of insects, mites, spiders and related invertebrates. John Wiley \& Sons, Ins.: New York, 1987a. 834-887p.

28. Hanski I. Carrion fly community dynamics: patchiness, seasonality and coexistence. Ecol Entomol 12: 257-266, 1987b.

29. Kaneshrajah G, Turner B. Calliphora vicina larvae grow at different rates on different body tissues. Int J Legal Med 118: 242-244, 2004.

30. Larraín PS, Salas CF. House fly (Musca domestica L.) (Diptera: Muscidae) development in different types of manure. Chilean J Agr Res 68: 192-197, 2008.

31. Montoyag AL, Sánchez JDR, Wolff ME. Sinantropía de Calliphoridae (Diptera) del Municipio La Pintada, Antioquia - Colombia. Rev Colomb Entomol 35: 73-82, 2009. 
32. Rosa TA, Babata LY, Souza CM, Sousa D, Mello-Patiou C, Mendes J. Dípteros de Interesse Forense em Dois Perfis de Vegetação de Cerrado em Uberlândia, MG. Neotrop Entomol 38: 859-866, 2009.

33. Salazar J L. Insectos de importância forense em cadáveres de ratas, Carabobo - Venezuela. Rev Peru Med Exp Salud Publica 23: 33-38, 2006.

34. Smith KGV. Manual of Forensic Entomology. British Museum, University Printing House, Cornell University Press: Oxford, 1986. 205p.

35. Souza AM, Linhares AX. Diptera and Coleoptera of potential forensic importance in southeastern Brazil: relative abundance and seasonality. Med Vet Entomol 11: 8-12, 1997.

36. Tabor KL, Fell RD, Brewster CC. Insect fauna visiting carrion in Southwest Virginia. Forensic Sci Int 150: 73-80, 2005.

37. Vasconcelos SD, Araujo MCS. Necrophagous species of Diptera and Coleoptera in northeastern Brasil: state of the art and challenges for the Forensic Entomologist. Rev Bras Entomol 56: 7-14, 2012.

38. Vitta A, Pumidonming W, Tangchaisuriya U, Poodendean C, Nateeworanart S. A preliminary study on insects associated with pig (Sus scrofa) carcasses in Phitsanulok, northern Thailand. Trop Biomed 24: 1-5, 2007.

39. Voss SC, Forbes, SL, Dadour IR. Decomposition and Insect Succession on cadavers inside vehicle environment. Forensic Sci Med Pathol 4: 22-32, 2008.

40. Zumpt F. Myiasis in man and animals in the Old World. Butterworth: London, 1987. 267p. 